УДК 811.134

\title{
А.А. Терещук
}

\section{ЯЗЫКОВАЯ ИДЕОЛОГИЯ ИСПАНСКОЙ ПАРТИИ «УОХ»}

Статья посвящена рассмотрению языковой идеологии представителей испанской крайней правой политической партии Vox. В ходе исследования были изучены программные документы партии, а также проанализированы интервью и публицистические статьи 52 депутатов от Vox в Конгрессе депутатов и 3 депутатов в Европейском парламенте за период с декабря 2018 г. по ноябрь 2019 г. Делается вывод о том, что представители Vох строят свою языковую идеологию на утверждении: испанскому языку в многоязычных автономных сообществах Испании угрожает опасность со стороны региональных языков. Партия предлагает отменить систему автономных сообществ и сделать испанский основным языком администрации и образования на территории всей страны. Миноритарные языки могут сохраниться в образовательной системе соответствующих регионов в качестве факультативных предметов. Особенное внимание представители Vох уделяют проблеме единства каталанского языка. Партия рассматривает валенсийский и балеарский как самостоятельные языки и поддерживает движения, направленные на языковой сепаратизм Валенсии и Балеарских островов от Каталонии.

Ключевые слова: языковая политика, правая идеология, каталонский сепаратизм, Vox, миноритарные языки.

DOI: $10.35634 / 2412-9534-2020-30-5-828-836$

\section{Введение}

2018-2019 гг. ознаменовались серьезными изменениями на политической сцене Испании. Стремительный рост популярности партии $\operatorname{Vox}^{1}$, идеологию которой обычно определяют как «крайнюю правую» [4. С. 39], стал феноменом, не только требующим осмысления с точки зрения политологии, но и нуждающемся в междисциплинарном анализе с использованием методов социологии, языкознания и культурологии. Партия, образованная в 2013 г., громко заявила о себе в декабре 2018 г., набрав 10,97 \% голосов на парламентских выборах в Андалусии [28]. В 2019 г. можно отметить значительное усиление позиций Vox: если на общеиспанских парламентских выборах в апреле ультраправые набрали рекордные для себя 10,26 \% голосов, то в ноябре получили уже 15,09\% (третье место в стране) [29]. Таким образом, в течение считанных месяцев на политическом горизонте появилась новая сила, которая опирается на идеологическую платформу, в целом ряде пунктов кардинально отличающуюся как от программы консервативной «Народной партии», так и более левых формаций.

Рост популярности Vох привлек к себе внимание как отечественных, так и зарубежных политологов и социологов. Специалисты изучили различные программные установки партии, обратив особенное внимание на отношение ее представителей к проблемам нелегальной иммиграции, феминизма и каталонского сепаратизма. Однако языковая идеология Vox до сих пор не была рассмотрена ни в публикациях российских ученых, ни в работах их зарубежных коллег. Авторы, обращающиеся к анализу идеологической платформы партии, единодушно отмечают неприятие испанскими крайними правыми регионального национализма и автономного устройства современной Испании (см., например: $[4 ; 7 ; 31 ; 44 ; 45 ; 47])$, но при этом не останавливаются на вопросе о том, как члены Vох планируют проводить языковую политику в многоязычной стране. В то же время распространенной в разных странах мира практикой является использование языка как инструмента «формирования или укрепления национальной государственности на основе этнической идентичности» [3. С. 43].

В некоторых публикациях представители Vox рассматриваются как «наследники» франкистского режима [11. С. 68]. Если согласиться с данным утверждением, можно сделать логическое заключение, что в вопросах языковой политики члены Vox должны ориентироваться на политику, реализуемую испанским государством в период диктатуры Ф. Франко (1936/39-1975). В отечественной научной литературе распространена точка зрения, согласно которой в период франкизма все региональные языки Испании находились под запретом $[1 ; 2 ; 14]$; данные последних исследований, посвященных данному вопросу, ставят под сомнение это утверждение $[15 ; 16]$. Сам факт того, что в российской науке отсутствует консенсус относительно характера языковой политики испанского госу-

\footnotetext{
${ }^{1}$ В русскоязычных СМИ иногда можно встретить перевод названия - «Голос»; далее - «Vох».
} 
дарства в период франкизма и что данный вопрос до сих пор является предметом научной дискуссии, затрудняет наше понимание идеологии Vox. Простая ссылка на сторонников партии, как на «франкистов»/《неофранкистов» недостаточна для объяснения того, какими принципами реализации языковой политики они руководствуются.

П. Пардо утверждает, что фактором, способствовавшим росту популярности Vox, стала реакция части общества на политический кризис в Каталонии [44]. В испанской прессе и в некоторых научных работах выдвигается предположение, что усиление Vох связано не только с каталонским кризисом, но и с антииммигрантской риторикой [26; 27; 45. Р. 917]; С. Д. Тернбулл-Дугарте в своем недавнем исследовании подробно разобрал эту идею и пришел к выводу, что вопрос об ограничении нелегальной иммиграции играет второстепенную роль в успехах крайних правых в Испании [47. Р. 7]. Вне зависимости от того, какой вклад в продвижение Vох внесло обращение к иммигрантской проблеме, не вызывает сомнения тот факт, что жесткая позиция членов партии по отношению к сепаратистским движениям внутри страны и предложение Vох ликвидировать систему автономий в Испании соответствуют ожиданиям части электората. При этом проблема языковой политики является одним из центральных вопросов во взаимоотношениях Мадрида с регионами (в первую очередь, с такими «проблемными» автономными сообществами, как Каталония и Страна Басков).

Таким образом, понимание принципов, на основании которых представители Vох предлагают осуществлять языковую политику, необходимо для изучения идеологической платформы этой молодой партии и для прогнозирования возможных изменений языковой политики испанского государства. Особенную актуальность данное исследование приобретает в контексте роста популярности крайних правых партий в Западной Европе, который отмечается в течение последнего десятилетия [11; 12].

\section{Методология исследования}

В настоящей статье рассматривается языковая идеология партии Vох. Языковая идеология может быть определена как «концептуальные представления о языках, носителях этих языков, а также применяемых ими дискурсивных практиках», - отмечает О.С. Гришечко [6. С. 64], рассматривая языковую идеологию как набор убеждений о языке, то есть, предлагая очень широкое определение данного явления.

Б. Спольски выделяет языковую идеологию в качестве одного из трех компонентов языковой политики и определяет ее как «speech community's consensus on what value to apply to each of the language variables or named language varieties... Put simply, language ideology is language policy with the manager left out, what people think should be done» [46. Р. 14]. Аналогично М. М. Раевская рассматривает языковую идеологию в связи с языковой политикой и показывает, что языковая идеология может являться одним из инструментов процессов нормативизации языка [13].

Анализ языковой идеологии Vox в настоящей статье строится на источниках двух типов. Источником первого типа являются две версии программы Vox, с которыми партия приняла участие в муниципальных и региональных выборах в мае 2019 г., а также манифест «100 мер для живой Испании» («100 medidas para la España viva»). «100 мер...» в краткой форме представляют идеологию Vох. Данные документы размещены на официальном сайте партии.

Второй тип источников представляют собой тексты интервью и публицистических статей членов Vox, ставших депутатами Конгресса депутатов (нижней палаты парламента Испании) по итогам выборов в ноябре 2019 г. и депутатами Европейского парламента по итогам выборов в мае 2019 г. В результате голосования партия получила 52 места в Конгрессе депутатов [22]; 3 представителя Vох в настоящий момент являются депутатами Европарламента [40]. Были проанализированы интервью и публицистические статьи 55 депутатов за период с декабря 2018 г. по ноябрь 2019 г. Нижняя временная граница соответствует моменту, когда Vox добилась успеха на выборах в парламент Андалусии; верхняя временная граница - последние парламентские выборы в Испании. Кроме того, для изучения заявленной темы мы решили проанализировать две программные статьи и два интервью идеолога и президента Vox C. Абаскаля, относящиеся к 2018 г.

Были рассмотрены высказывания на тему языковой политики 20 представителей Vox в Конгрессе депутатов и одного представителя в Европейском парламенте. Естественно, что не все политики обращались к проблеме языковой политики; этот вопрос интересовал в первую очередь представителей многоязычных автономных сообществ. 


\section{Угроза испанскому языку}

Необходимость изменения языковой политики в современной Испании вытекает из идеи представителей Vox об опасности, которая угрожает испанскому языку в автономных сообществах, в которых он сосуществует с миноритарными идиомами. Данное представление находит отражение как в текстах программных документов партии, так и в некоторых проанализированных интервью и публицистических статьях.

В документе «100 мер...» содержатся намеки на угрозу испанскому языку. В пункте № 4 указывается, что никакая администрация и никакое частное лицо не могут принижать значение испанского языка и дискриминировать его. Пункт № 60 предлагает потребовать должного признания испанского языка на международном уровне [49]. В обоих случаях можно заметить, что речь идет об абстрактных требованиях, воздействующих на эмоции избирателя, но не подразумевающих какихлибо конкретных действий.

Интервью и статьи депутатов Vох дают больше определенности в данном вопросе. Абаскаль, рассуждая о сепаратистских движениях в Испании, подверг резкой критике языковую политику правительств автономных сообществ и назвал ее «лингвистическим апартеидом испанского» [38]. Генеральный секретарь партии X. Ортега Смит подхватил выражение президента Vох и точно так же охарактеризовал языковую политику в Галисии [37]. Депутат М. Ромеро обвинила «Народную партию» в том, что она не защитила «как следовало» испанский язык в таких регионах, как Галисия или Балеарские острова [36]. Подобные оценки языковой политики могут быть связаны с активным продвижением в некоторых автономных сообществах региональных языков в образовательной сфере, в администрации, на радио и телевидении.

Члены Vox не являются авторами идеи об угрозе для испанского языка в многоязычных автономных сообществах. Представление о том, что расширение сферы употребления миноритарных языков в регионах может негативно сказаться на будущем общенационального языка, характерно для части испанского общества XXI в. (см.: [2]). Тем не менее, именно крайние правые смогли использовать опасения части жителей страны в связи с положением испанского языка в автономиях для достижения своих политических целей. Выдвинув тезис о существующей угрозе общенациональному языку, представители Vox предложили пути решения данной проблемы.

\section{Языковая политика в автономных сообществах}

Как уже было отмечено выше, одной из громких инициатив Vox является предложение об отмене системы автономных сообществ и о предоставлении равных прав всем провинциям Испании. Первым (!) пунктом в перечне «100 мер...» является требование отмены автономии Каталонии [49]. В то же время в программе для региональных выборов указывается, что Vох выступает за уничтожение всей системы автономных сообществ [50]. За отмену автономий высказываются и все представители Vox, которым в ходе интервью задавали вопрос на данную тему (например: [17; 25; 35]).

Последствия подобной отмены для языковой ситуации в многоязычных регионах можно проследить на примере декрета, выпущенного властями Национальной Испании 8 апреля 1938 г. [18]. Данный документ отменил действие Статута об автономии Каталонии, принятого в 1932 г. После публикации декрета управление каталонскими провинциями должно было осуществляться в соответствии с теми же принципами, что и остальными провинциями Испании. Таким образом, в качестве языка администрации должен был использоваться только испанский. Исключение каталанского из административной сферы дало повод националистам говорить о «репрессиях» против регионального идиома [32]. Хотя правительство Испании и не проводило политики, направленной на уничтожение каталанского [15], исключение данного языка из некоторых сфер употребления оказало негативное влияние на процесс его кодификации и нормативизации. Как указывают А.А. Евдокимова и Е.А. Гринина, «всерьез говорить о запуске нормализационных процессов можно лишь после принятия Конституции 1978 г.» [9. C. 80]. Можно предположить, что в случае, если Vох в будущем сможет пролоббировать отмену системы автономий, события будут развиваться по аналогичному сценарию и миноритарные языки de facto будут исключены из административной сферы.

Вопрос о лишении официального статуса региональных языков напрямую не прописан в программных документах Vox, и в некоторых автономиях теоретически могут сохраниться вторые языки в качестве коофициальных. В то же время можно с уверенностью утверждать, что первым языком в административной и образовательной сфере будет испанский. Пункт № 4 «100 мер...» говорит о не- 
обходимости строго следовать Конституции, в соответствии с которой каждый испанец имеет право использовать испанский язык. Кроме того, в данном пункте требуется сделать владение региональным языком необязательным для работы в правительственных органах в соответствующих автономных сообществах.

Пункт № 62 данного документа заявляет о праве граждан получать образование на испанском языке в любом регионе страны. Коофициальные языки могут быть лишь «опциональными»: «Испанский должен в обязательном порядке быть языком обучения, а коофициальные языки - по выбору». Так как в первой части предложения говорится об обязательности использования именно испанского в качестве языка обучения, можно предположить, что применительно к коофициальным языкам речь идет о возможности выбора данных языков в качестве предмета обучения (если допустить, что речь идет о возможности выбора регионального идиома в качестве языка обучения, то теряет смысл первая часть высказывания). В случае реализации данной идеи можно будет говорить об откате к временам раннего франкизма в вопросе о присутствии миноритарных языков в образовательной системе. В 1944 г. в испанских университетах появилась каталанская филология в качестве обязательного предмета на кафедрах романской филологии [43, p. 19]. Обязательное преподавание региональных языков в рамках дошкольного и среднего школьного образования было введено Ф. Франко в 1975 г., в самом конце диктатуры [19]. Таким образом, в данном вопросе члены Vох предлагают отказаться от мер по введению миноритарных языков в образовательную систему, принятых в период франкизма, и выдвигают более радикальную программу, чем испанские правые XX в. (то есть, факультативный, а не обязательный характер преподавания региональных языков).

\section{Культурно-языковой сепаратизм}

Как было отмечено выше, одним из решающих факторов, способствовавших росту популярности Vox, стала жесткая позиция партии по вопросу урегулирования кризиса в Каталонии. Представители партии не только обрушиваются с критикой на националистов, но и высказываются по вопросу о единстве каталанского языка.

В большинстве научных работ валенсийский и балеарский определяются как диалекты (разновидности) каталанского языка (см., например: [20. Р. 10; 30. Р. 264; 33. Р. 107; 41. Р. 462]). Однако после смерти Франко и начала процесса перехода к демократии в публицистике соответствующих автономных сообществ эти два идиома начали определяться как отдельные языки. В Валенсии движение, отрицающее единство каталанского и позиционирующее валенсийский как самостоятельный язык, получило название «блаверизмо» [8. С. 92]. Аналогичное движение на Балеарских островах называется «гонельизмо» [23]. В настоящее время, по данным социологических опросов, только $1 \%$ жителей Валенсии и $11 \%$ жителей Балеарских островов считают своим родным языком каталанский; $39 \%$ и $47 \%$ соответственно называют своими родными языками валенсийский ${ }^{2}$ и балеарский / мальоркский [8. С. 95]. Спор о проблеме язык/диалект в данных регионах выходит за чисто лингвистические рамки и приобретает ряд исторических, политических и культурных аспектов. Например, в Валенсии некоторые сторонники блаверизмо даже отрицают свое происхождение от каталонцев, заселивших данную территорию во время Реконкисты, и рассматривают в качестве своих предков мосарабов или даже выходцев из Северной Африки [10. С. 82].

Ж. Мира рассматривает «языковой антикаталанизм» как «субпродукт политико-идеологического антикаталанизма» [42. Р. 75]. Г. В. Денисенко указывает, что важную роль в распространении языкового сепаратизма (в частности, идей блаверизмо) в конце 1970-х - начале 1980-х гг. сыграла правоцентристская партия «Союз демократического центра» [8. С. 92]. Эта формация объединяла представителей очень разнородных политических течений, в том числе и бывших франкистов [34. Р. 202]. Впоследствии идеи языкового сепаратизма были поддержаны правоцентристской «Народной партией». Таким образом, языковая сецессия на территориях распространения каталанского языка оказывается связанной с правыми политическими силами постфранкистской Испании.

Vox придает большое значение признанию валенсийского и балеарского отдельными языками, отличными от каталанского. Абаскаль заявляет, что он и его сторонники «отрицают языковое единство между валенсийским и каталанским» [48]. Лидер Vox призывает опираться на т. н. «нормы Пу-

\footnotetext{
${ }^{2}$ Термин «валенсийский» применительно к данному идиому использовался и ранее, начиная с XIV-XV вв., но при этом не ставилось под сомнение культурно-языковое единство Каталонии и Валенсии.
} 
ча», выработанные в 1979 г. и подчеркивающие различия между валенсийским и каталанским. В настоящее время Валенсийская академия языка опирается на «Кастельонские нормы», которые отталкиваются от положения о единстве каталанского и валенсийского. Предложение Абаскаля использовать «нормы Пуча» подразумевает необходимость внести значительные изменения в современное использование валенсийского в письменной форме.

Депутат от Кастельона дивизионный генерал А. Асарта, используя военную терминологию, заявил, что «здесь, в Кастельоне, мы находимся на передовой линии борьбы против панкаталанизма» [21]. Метафора тем более интересна, что провинция Кастельон расположена на границе с Каталонией, а ее столица, Кастельон-де-ла-Плана, ассоциируется с вышеупомянутыми кастельонскими нормами валенсийского. Далее депутат пожаловался на «навязывание» каталанского языка в администрации и в школах провинции.

Об аналогичном «навязывании» сверху каталанского языка рассуждают и представители Vox с Балеарских островов. Депутат А. Сальва говорит о том, что власти пытаются каталанизировать острова, начиная с 1920-х гг. Оценивая современную языковую ситуацию в автономном сообществе, представитель Vox жалуется, что правительство региона требует использовать каталанский «для всего» («para todo»). В своем интервью депутат допускает крайне резкие выпады против каталанского языка, заявляя, что каталанский - это самая худшая болезнь (!), от которой страдают современные Балеары. В будущем Сальва обещает стать «острием копья антикаталанизма» [39].

Столь резкая антикаталанская риторика сочетается у представителей Vox с идеей о самобытности и уникальности балеарского и даже мальоркского языка. Депутат К. Эстебан в издании Diari Balear опубликовала статью, в которой выразила сожаление, что «мальоркский язык» гибнет, вытесняемый каталанским. Эстебан указывает, что жителям Мальорки «навязали язык другого региона Испании». Показательно, что текст статьи написан по-испански с добавлением отдельных лексем, характерных для каталанского языка на Балеарах [24].

Можно предположить, что столь резкая оценка распространения каталанского языка и поддержка культурно-языковой сецессии Валенсии и Балеарских островов партией Vох являются реакцией на каталонский национализм и политический кризис в Каталонии. Как отмечает Гринина, в борьбе отдельных частей Испании за отделение от единой страны языку «отведена очень существенная роль» [5. С. 87]. Постоянные апелляции лидеров каталонских националистов к проблеме защиты регионального языка могли стать причиной проявления антикаталанского дискурса в предвыборной кампании крайних правых.

\section{Заключение}

Проведенное исследование показало исходное положение, от которого отталкиваются представители Vox, вырабатывая основы своей языковой идеологии, и два важных аспекта языковой политики испанских крайних правых. Базовым положением для Абаскаля и его единомышленников является идея об опасности, которая угрожает испанскому языку в многоязычных автономных сообществах. Миноритарные языки, по мнению Vox, занимают доминирующее положение в административной и образовательной сфере своих автономий. Сложившаяся ситуация ущемляет права испаноговорящих граждан и является «лингвистическим апартеидом», по выражению представителей партии.

Vох выступает за отмену системы автономных сообществ. В новой, реформированной Испании первым языком администрации и образования должен стать испанский; региональные языки могут употребляться лишь опционально. Языком обучения в школе и университете должен быть только испанский. Региональные языки могут изучаться в качестве предмета, однако этот предмет должен быть факультативным. Можно предположить, что в долгосрочной перспективе реализация данного предложения будет способствовать снижению частоты использования миноритарных языков и в конечном итоге теоретически может привести к их исчезновению.

Предлагая ограничить сферу употребления региональных языков, депутаты от Vox одновременно парадоксальным образом выставляют себя в качестве защитников валенсийского и балеарского вариантов каталанского языка. В данном вопросе современные крайние правые является продолжателями политики правоцентристских партий в постфранкистской Испании. Члены Vох выступают с резкой критикой идей панкаталанизма и определяют валенсийский и балеарский как самостоятельные языки. Поддержка языковой сецессии Валенсии и Балеарских островов может быть связана с реакцией Абаскаля и его коллег на каталонский сепаратизм. 


\section{СПИСОК ЛИТЕРАТУРЫ И ИСТОЧНИКОВ}

1. Авилова Н.С. Языковая политика в Каталонии в период диктатуры Франко // Иберо-романистика в современном мире. Научная парадигма и актуальные задачи: тезисы V международной конференции. М., 2010. С. 5-6.

2. Астахова Е.В. Манифест в защиту испанского языка - политическое и языковое измерение // Филологические науки в МГИМО. 2009. № 36 (51). С. 1-6.

3. Белов С.А., Кропачев Н.М., Соловьев А.А. Разработка концепции и нормативо-правовое обеспечение государственной языковой политики Российской Федерации // Вестник Санкт-Петербургского университета. Право. 2017. Т. 8. Вып. 1. С. 42-61.

4. Верников В.Л. Парламентские выборы в Испании: социалисты вернулись во власть, и теперь - надолго // Научно-аналитический Вестник Института Европы РАН. 2019. № 3. С. 36-41.

5. Гринина Е.А. Язык как инструмент политики // Ибероамериканские тетради. 2017. № 1 (15). С. 86-89.

6. Гришечко О.С. Языковая идеология: теория описания и практика воплощения // Филологические науки. Вопросы теории и практики. 2017. № 11 (77). С. $62-65$.

7. Дементьев А.В. Неофранкизм и проблема территориальной целостности современной Испании // Вестник МГИМО университета. 2019. № 1 (64). С. 129-146.

8. Денисенко Г.В. Каталония, Валенсия, Балеарские острова: к вопросу о культурно-языковом сепаратизме // Ибероамериканские тетради. 2017. № 1 (15). С. 90-96.

9. Евдокимова А.А., Гринина Е.А. Региональные языки Испании: нормализация, нормативизация, кодификация // Вестник Московского государственного лингвистического университета. Гуманитарные науки. 2018. № 2 (791). С. 77-88.

10. Кожановский А.Н. Испания: этнический фактор и административные границы // Общественные науки и современность. 2002. № 6. С. 78-89.

11. Осколков П.В. Динамика национализма и популизма в ЕС: продолжающиеся тренды и новые явления // Европейский Союз: факты и комментарии. 2019. № 95. С. 68-72.

12. Осколков П.В. Мультикультурализм и европейские правые: в поисках другого // Современная Европа. 2019. № 3. C. 83-91.

13. Раевская М.М. Языковая идеология как ментальная модель и исследовательская парадигма // Вестник Московского университета. Серия 19: лингвистика и межкультурная коммуникация. 2019. № 2. С. 24-35.

14. Разумихина Д.В. Процессы нормализации каталанского языка: автореф. дис. ... канд. филол. наук. М.: МГУ, 1991. $20 \mathrm{c}$.

15. Терещук А.А. «Говори на языке империи»: К вопросу о положении каталанского языка в период правления Ф. Франко (1939-1975) // Вестник Челябинского государственного университета. Филологические науки. 2018. Вып. 112. № 4 (414). С. 153-162.

16. Терещук А.А. Нормативно-правовое обеспечение языковой политики правительства Испании в Каталонии в период франкизма // Вопросы иберо-романистики. Вып. 17: сб. ст. М.: МАКС Пресс, 2019. С. 293-301.

17. ABC. 2019. 30 de marzo. URL: https://www.abc.es/espana/abci-ignacio-garriga-suspenderemos-generalitat-hasta-derrotagolpismo-201903300139_noticia.html.

18. Boletín oficial del Estado. 1938. 8 de Abril. № 534. P. 6674.

19. Boletín Oficial del Estado. 1975. 1 de Julio. № 156. P. 14249-14250.

20. Brauli A. La llengua catalana: presentació general // Gramàtica del català contemporani. Vol. 1, Barcelona: Empúries, 2008. P. 5-33.

21. Castellón Diario. 2019. 23 de abril. URL: https://castellondiario.com/alberto-asarta-concede-una-entrevista-castellondiario/.

22. Congreso de los Diputados. URL: http://www.congreso.es/.

23. Denisenko G. El catalán balear y el movimiento de gonellismo // Cuadernos Iberoamericanos. 2014. № 2 (4). P. 25-29.

24. Diari Balear. 2019. 9 de enero. URL: https://www.diaribalear.es/pensat-i-fet-el-mallorquin-igual-que-el-lince/.

25. El Día de Segovia. 2019. 19 de noviembre. URL: https://www.eldiasegovia.es/noticia/Z1DB562FE-E123-F44D1D7C7AF53843CBBD/Tambien-venimos-a-ayudar-a-los-que-nos-llaman-fascistas.

26. El País. 2018. 3 de diciembre. URL: https://elpais.com/politica/2018/12/03/actualidad/1543829876_200181.html.

27. El País. 2018. 4 de octubre. URL: https://elpais.com/politica/2018/10/03/actualidad/1538585644 517997.html.

28. El País. Elecciones autonómicas 2018. URL: https://resultados.elpais.com/elecciones/2018/autonomicas/01/ index.html.

29. El País. Elecciones generales. Resultados. Total España. URL: https://resultados.elpais.com/elecciones/2019/ generales/congreso/.

30. Fernández Planas A., Roseano P., Elvira García W., Cerdà Massó R., Romera Barrios L., Carrera Sabaté J., Szmidt Syerikow D., Labraña Barrero S., Martínez Celdrán E. Cap a un nou mapa dialectal del català? Consideracions a partir de dades prosòdiques tractades dialectomètricament // Estudios de fonética experimental. 2015. XXIV. P. 257-286.

31. Fernández G. Dos estrategias para la extrema derecha // Estudios de política exterior. 2019. № 188. URL: https://www.politicaexterior.com/articulos/politica-exterior/dos-estrategias-la-extrema-derecha/. 
32. Ferrer i Gironès F. La persecució política de la llengua catalana. Història de les mesures preses contra el seu ús des de la Nova Planta fins avui. Barcelona, 1985. 308 p.

33. Griera A. Dialectología catalana. Barcelona: Escuela de Filología, 1949. 152 p.

34. Gunther R., Montero J.R., Linz J. Political Parties: Old Concepts and New Challenges. Oxford: Oxford University Press, 2002. $384 \mathrm{p}$.

35. Huelva información. 2019. 4 de noviembre. URL: https://www.huelvainformacion.es/huelva/Huelva-ralentizadaproblema-infraestructuras_0_1406559618.html .

36. La Tribuna del País Vasco. 2019. 24 de abril. URL: https://atribunadelpaisvasco.com/art/10860/reyes-romero-laspoliticas-de-genero-tambien-perjudican-a-las-mujeres.

37. La Voz de Galicia. 2019. 18 de enero. URL: https:/www.lavozdegalicia.es/noticia/galicia/2019/01/17/galiciapretende-levantar-apartheids-linguisticos-proteger-espanol/00031547744811799286268.htm.

38. Libertad Digital. 2018. 26 de marzo. URL: https:/www.libertaddigital.com/opinion/santiago-abascal/la-derrota-delseparatismo-llevara-anos-84718/.

39. Mallorca Diario. 2019. 30 de octubre. URL: https://www.mallorcadiario.com/entrevista-a-antonio-salva.

40. Members of the European Parliament. URL: http://www.europarl.europa.eu/meps/en/home.

41. Milà i Fontanals M. De los trovadores en España. Estudio de la lengua y poesía provenzal. Barcelona: Librería de Joaquín Verdaguer, 1861. 550 p.

42. Mira J. Llengua i identitat al País Valencià // Llengua i identitat, Barcelona: Universitat de Barcelona. 2008. P. 67-82.

43. Ordenación de la Facultad de Filología y Letras. Decreto de 7 de julio de 1944. Barcelona: Castells. 1944.

44. Pardo P. Make Spain Great Again // Foreign Policy. 2019. URL: https://foreignpolicy.com/2019/04/27/vox-spainelections-trump-bannon/.

45. Sanjuán V. C., Goetzenberger M. M. Los partidos populistas de extrema derecha en España: Un análisis sociológico comparado // Izquierdas. 2020. № 49. P. 910-931.

46. Spolsky B. Language Policy. Cambridge: Cambridge University Press, 2005. 250 p.

47. Turnbull-Dugarte S. J. Explaining the end of Spanish exceptionalism and electoral support for Vox // Research and Politics. 2019. Vol. 6. Issue 2. P. 1-8.

48. Valencia News. 2018. 25 de febrero. URL: https://hemeroteca.valencianews.es/politica/santiago-abascal-voxnegamos-la-unidad-linguistica-entre-valenciano-y-catalan/.

49. Vox. 100 medidas urgentes de VOX para España. URL: https://www.voxespana.es/noticias/100-medidas-urgentesde-vox-para-espana-20181006.

50. Vox. Programa electoral para las elecciones autonómicas de 2019. URL: https://www.voxespana.es/programaelecciones-autonomicas-2019.

Поступила в редакцию 30.07.2020

Терещук Андрей Андреевич, Ph. D., доцент кафедры романской филологии института иностранных языков

ФГБОУ ВО «Российский государственный педагогический университет им. А.И. Герцена»

191186, Россия, г. Санкт-Петербург, Наб. р. Мойки, 48

E-mail: atereschuk@herzen.spb.ru; san_petersburgo@inbox.ru

\section{A.A. Tereshchuk \\ LANGUAGE IDEOLOGY OF SPANISH POLITICAL PARTY "VOX"}

DOI: $10.35634 / 2412-9534-2020-30-5-828-836$

The article analyzes the language ideology of Spanish far-right political party "Vox". The documents containing the party program have been studied, and interviews and newspaper articles issued by 52 representatives of "Vox" in the Congress of Deputies and 3 representatives in the European Parliament in the period from December 2018 to November 2019 have been analyzed. The article concludes that "Vox" bases its language ideology on the supposition that the Spanish language in multilingual autonomous communities is endangered by the development of minority languages. According to "Vox", Spanish should be the first language in administration and education on the whole territory of the country. Minority languages may remain in the educational system of the respective regions as optional subjects. The members of "Vox" dedicate a special attention to the question of integrity of the Catalan language. The party considers Valencian and Balearic as independent languages and not as varieties of Catalan. The party supports movements aimed at the linguistic separatism of Valencia and the Balearic Islands from Catalonia.

Keywords: language policy, right-wing ideology, Catalan separatism, Vox, minority languages. 


\section{REFERENCES}

1. Avilova N.S. Yazykovaia politika v Katalonii v period diktatury Franko [Language policy in Catalonia during Franco's dictatorship], Iberoromanistics in modern world. Scientific paradigm and actual tasks: V international conference proceedings, Moscow, 2010, pp. 5-6. (in Russian)

2. Astahova E.V. Manifest v zaschitu ispanskogo yazyka - politicheskoe i yazykovoe izmerenie [Spanish language defense manifesto - political and linguistical dimension], Philological science at MGIMO, 2009, no. 36 (51). (in Russian)

3. Belov S.A., Kropachev N.M., Soloviev A.A. Razrabotka kontsepsii i normativno-pravovoe obespechenie gosudarstvennoi yazykovoi politiki Rossiiskoi Federatsii [Elaboration of conception and legal regulation of state language policy of Russian Federation], Saint-Petersburg State University Herald. Law, 2017, vol. 8, issue 7, pp. 42-61. (in Russian)

4. Vernikov V.L. Parlamentskie vybory v Ispanii: sotsialisty vernulis vo vlast - i teper nadolgo [Parliamentary election in Spain: Socialists have returned to power, and now - for a long time], Scientific Herald of Institute of Europe of Russian Academy of Science, 2019, no. 3, p. 36-41. (in Russian)

5. Grinina E.A. Yazyk kak instrument politiki [Language as instument of politics], Iberoamerican issues, 2017 , no. 1 (15), pp. 86-89. (in Russian)

6. Grishechko O.S. Yazykovaia ideologia: teoria opisania i praktika voploshenia [Language ideology: theory of description and practice of realization], Filologuicheskie nauki. Voprosy teorii i praktiki, 2017, no. 11 (77), pp. 62-65. (in Russian)

7. Dementiev A.V. Neofrankizm i problema territorialnoi tselostnosti sovremennoi Ispanii [Neo-Francoism and the question of territorial integrity of modern Spain], MGIMO University Herald, 2019, no. 1 (64), pp. 129-146. (in Russian)

8. Denisenko G.V. Katalonia, Valensia, Balearskie ostrova: k voprosu o kulturno-yazykovom separatizme [Catalonia, Valencia, Balearic islands: towards the question of cultural and linguistical separatism], Iberoamerican issues, 2017, no. 1 (15), pp. 90-96. (in Russian).

9. Evdokimova A.A., Grinina E.A. Regionalny yazyki Ispanii: normalizatsia, normativizatsia, kodifikatsia [Regional languages of Spain: normalizaton, normativization, codification], Moscow State Linguistical University Herald. Humanities, 2018, no. 2 (791), pp. 77-88. (in Russian)

10. Kozhanivski A.N. Ispania: etnicheski faktor i administrativnye granitsy [Spain: ethnical factor and administrative borders], Social sciences and modernity, 2002, no. 6, pp. 78-89. (in Russian)

11. Oskolkov P.V. Dinamika natsionalizma i populizma v ES: prodolzhaiushiesia trendy i novye yavlenia [Nationalism and populism dynamics in EU: continuing trends and new phenomena], European Union: facts and commentaries, 2019, no. 95, pp. 68-72. (in Russian)

12. Oskolkov P.V. Multikulturalizm i evropeiskie pravye: v poiskah drugogo [Multiculturalism and european Right: searching for the other], Modern Europe, 2019, no. 3, pp. 83-91. (in Russian)

13. Razumihina D.V. Protsessy normalizatsii katalanskogo iazyka [Processes of normalization of the Catalan language], Moscow: MGU, 1991. (in Russian)

14. Raevskaia M.M. Yazykovia ideologia kak mentalnaia model i issledovatelskaia paradigm [Language Ideology as a Mental Model and Research Paradigm], Vestnik Moskovskogo universiteta. Seria 19: lingvistika I mezhkulturnaia kommunikatsia, 2019, no. 2, pp. 24-35. (in Russian).

15. Tereshchuk A.A. "Govori na yazyke imperii": k voprosu o polozhenii katalanskogo yazyka v period diktatury F. Franko (1939-1975) ["Speak the language of the Empire": Towards the question of situation of the Catalan language during F. Franco's dictatorship (1939-1975)], Cheliabinsk University Herald. Philology, 2018, issue 112, no. 4 (414), pp. 153-162. (in Russian)

16. Tereshchuk A.A. Normativno-pravovoe obespechenie gosudarstvennoi yazykovoi politiki v Ispanii vo vremia diktatury F. Franko [The normative legal provision of the state language policy in Spain during F. Franco's dictatorship], Issues of iberoromanistics, Moscow: Max Press, 2019, pp. 293-301. (in Russian)

17. ABC. 2019. 30 de marzo. URL: https://www.abc.es/espana/abci-ignacio-garriga-suspenderemos-generalitat-hastaderrota-golpismo-201903300139 noticia.html.

18. Boletín oficial del Estado. 1938. 8 de Abril. № 534. P. 6674.

19. Boletín Oficial del Estado. 1975. 1 de Julio. № 156. P. 14249-14250.

20. Brauli A. La llengua catalana: presentació general // Gramàtica del català contemporani. Vol. 1. Barcelona: Empúries, 2008. P. 5-33.

21. Castellón Diario. 2019. 23 de abril. URL: https://castellondiario.com/alberto-asarta-concede-una-entrevistacastellon-diario/.

22. Congreso de los Diputados. URL: http://www.congreso.es/.

23. Denisenko G. El catalán balear y el movimiento de gonellismo // Cuadernos Iberoamericanos. 2014. № 2 (4). P. 25 -29.

24. Diari Balear. 2019. 9 de enero. URL: https:/www.diaribalear.es/pensat-i-fet-el-mallorquin-igual-que-el-lince/.

25. El Día de Segovia. 2019. 19 de noviembre. URL: https://www.eldiasegovia.es/noticia/Z1DB562FE-E123-F44D1D7C7AF53843CBBD/Tambien-venimos-a-ayudar-a-los-que-nos-llaman-fascistas.

26. El País. 2018. 3 de diciembre. URL: https://elpais.com/politica/2018/12/03/actualidad/1543829876_200181.html. 
27. El País. 2018. 4 de octubre. URL: https://elpais.com/politica/2018/10/03/actualidad/1538585644 517997.html.

28. El País. Elecciones autonómicas 2018. URL: https://resultados.elpais.com/elecciones/2018/autonomicas/ 01/ index.html.

29. El País. Elecciones generales. Resultados. Total España. URL: https://resultados.elpais.com/elecciones/2019/ generales/congreso/.

30. Fernández Planas A., Roseano P., Elvira García W., Cerdà Massó R., Romera Barrios L., Carrera Sabaté J., Szmidt Syerikow D., Labraña Barrero S., Martínez Celdrán E. Cap a un nou mapa dialectal del català? Consideracions a partir de dades prosòdiques tractades dialectomètricament, Estudios de fonética experimental. 2015. XXIV. P. 257-286.

31. Fernández G. Dos estrategias para la extrema derecha, Estudios de política exterior. 2019. № 188. URL: https://www.politicaexterior.com/articulos/politica-exterior/dos-estrategias-la-extrema-derecha/.

32. Ferrer i Gironès F. La persecució política de la llengua catalana. Història de les mesures preses contra el seu ús des de la Nova Planta fins avui. Barcelona, 1985. $308 \mathrm{p}$

33. Griera A. Dialectología catalana. Barcelona: Escuela de Filología, 1949. 152 p.

34. Gunther R., Montero J.R., Linz J. Political Parties: Old Concepts and New Challenges. Oxford: Oxford University Press, 2002. $384 \mathrm{p}$

35. Huelva información. 2019. 4 de noviembre. URL: https://www.huelvainformacion.es/huelva/Huelva-ralentizadaproblema-infraestructuras 0 1406559618.html.

36. La Tribuna del País Vasco. 2019. 24 de abril. URL: https://latribunadelpaisvasco.com/art/10860/reyes-romero-laspoliticas-de-genero-tambien-perjudican-a-las-mujeres.

37. La Voz de Galicia. 2019. 18 de enero. URL: https://www.lavozdegalicia.es/noticia/galicia/2019/01/17/galiciapretende-levantar-apartheids-linguisticos-proteger-espanol/00031547744811799286268.htm.

38. Libertad Digital. 2018. 26 de marzo. URL: https:/www.libertaddigital.com/opinion/santiago-abascal/la-derrota-delseparatismo-llevara-anos-84718/.

39. Mallorca Diario. 2019. 30 de octubre. URL: https://www.mallorcadiario.com/entrevista-a-antonio-salva.

40. Members of the European Parliament. URL: http://www.europarl.europa.eu/meps/en/home.

41. Milà i Fontanals M. De los trovadores en España. Estudio de la lengua y poesía provenzal. Barcelona: Librería de Joaquín Verdaguer, 1861. 550 p.

42. Mira J. Llengua i identitat al País Valencià. Llengua i identitat, Barcelona: Universitat de Barcelona. 2008. P. 67-82.

43. Ordenación de la Facultad de Filología y Letras. Decreto de 7 de julio de 1944. Barcelona: Castells. 1944.

44. Pardo P. Make Spain Great Again, Foreign Policy. 2019. URL: https://foreignpolicy.com/2019/04/27/vox-spainelections-trump-bannon/.

45. Sanjuán V.C., Goetzenberger M.M. Los partidos populistas de extrema derecha en España: Un análisis sociológico comparado, Izquierdas. 2020. № 49. P. 910-931.

46. Spolsky B. Language Policy. Cambridge: Cambridge University Press, 2005. 250 p.

47. Turnbull-Dugarte S. J. Explaining the end of Spanish exceptionalism and electoral support for Vox, Research and Politics. 2019. Vol. 6. Issue 2. P. 1-8.

48. Valencia News. 2018. 25 de febrero. URL: https://hemeroteca.valencianews.es/politica/santiago-abascal-voxnegamos-la-unidad-linguistica-entre-valenciano-y-catalan/.

49. Vox. 100 medidas urgentes de VOX para España. URL: https://www.voxespana.es/noticias/100-medidas-urgentesde-vox-para-espana-20181006.

50. Vox. Programa electoral para las elecciones autonómicas de 2019. URL: https://www.voxespana.es/programaelecciones-autonomicas-2019.

Received 30.07.2020

Tereshchuk A.A., Ph. D., Associate Professor at Department of Romance Philology,

Institute of Foreign Languages

Herzen State Pedagogical University

Moika emb., 48, Saint-Petersburg, Russia, 191186

E-mail: atereschuk@herzen.spb.ru; san_petersburgo@inbox.ru 